\title{
THE ADOPTION OF SYSTEMIC THINKING IN PUBLIC MANAGEMENT: A PARADIGM SHIFT
}

\section{REVIEW ARTICLE}

REBELO, Michele Alves Correa ${ }^{1}$

REBELO, Michele Alves Correa. The adoption of systemic thinking in public management: a paradigm shift. Revista Científica Multidisciplinar Núcleo do Conhecimento. 04 year, Ed. 10, Vol. 01, pp. 45-63. October 2019. ISSN: 2448-0959, Access link in: https://www.nucleodoconhecimento.com.br/businessadministration/thought-systemic

\section{SUMMARY}

Given the current Brazilian political scenario and the changes in the panorama of public management in the 21ST century, this article aims to present the reflections of the adoption of systemic thinking by the public manager evidencing the influence that this thought Decision-making. It is inferred from a research of applied nature, of an exploratory objective, with the adoption of bibliographic research. This is an important issue, due to the difficulty of the public manager to achieve efficiency in the execution of administrative activities. With the research it was possible to observe that the systemic thinking of the manager influences the direction of public management, the benefits of this posture can be visible in the services provided to society and internal actions of the institution. Nowadays, it is observed the personality in decision-making, due to the political influence of the state and because it is a highly competitive scenario, where personal vanity and the culture of immediacy prevail. Systemic thinking contributes to new emerging visions becoming shared and collaborative. Public

\footnotetext{
${ }^{1}$ Master in Public policy management - UNIVALI. Specialist in criminal and procedural law-School of the magistracy of Santa Catarina. Specialist in public safety management - UNIVALI. Law degree - FEBE.
}

Disponível em: https://www.nucleodoconhecimento.com.br/business-administration/thought- 
management lacks systematic innovation of thinking to meet social needs and achieve efficiency.

Keywords: public management, public manager, principle of efficiency, systemic thinking.

\section{INTRODUCTION}

The present research proposes to demonstrate to the readers the reflections of the adoption of systemic thinking by the public manager and how this can influence people's lives.

Since the decade of 80 , a growing movement has been observed in search of modern and efficient management techniques, capable of providing improvements in public services (KETTL, 2005; PAULA, 2005; MANNING et al., 2009). In parallel to this reality, the public manager has come across a new global environment, new social demands, new technologies and project concepts.

Because of these factors, the way to administer public services has been transforming. The bureaucratic model is being replaced by the managerial and the political, social and cultural changes begin to interfere in the way of thinking of society.

In spite of this advancement in the concepts of management and public administration, it is perceived the difficulty of the public manager to achieve efficiency in the execution of its activities. This is due to the prioritization of the particular interests of the nominees to the positions of direction, leadership and advisory, as well as the political influence on the decision making of public managers.

According to the board (2009), the function of direction, made possible by access to the public position classified as of free provision, implies expectations of the performance of the position associated with the political interests of those who have the power to appoint. For this reason, personal loyalty is required of the appointed. This is a precarious link and can be exonerated at any time. 
In the Brazilian administrative tradition, only the most technical nucleus of the state tends to have high-management positions preserved from markedly political appointments (FLEURY, 2009). Ideally, these positions would be occupied by people who had technical knowledge. However, it is adopted in most cases, subjective naming criterion.

The focus of this work is to seek a reflection on a new posture of the public manager in the face of this problem. It will be necessary to address in a perfunctory manner, aspects of a subjective nature, such as the character of the manager, which determines the moral or social behaviour and, consequently, the direction of good or bad management.

Public management lacks new postures of power and leadership. A systemic innovation of thinking should occur at any point in the institution. It is not only about doing different things, but doing the same things in different ways, creating, as Peter Drucker mentions (2002), new satisfaction potentials.

Given the complexity of the theme and from a systematic analysis, we have the right and the manager as open systems, which relate in a dynamic tuning. They are in continuous and incessant process of exchanges and exchanges with the environment. Organizations are systems of roles played by people (CHIAVENATO, 2000).

Under the vision and contribution of the social sciences, there is the possibility of conducting the research based on Bertalanffy's Theory (1937), which has a different view of the scientific reductionism until then applied by conventional science.

According to Valença (2011), the systemic approach is directly associated with the reading of the complexity of reasoning, mastery or the supervenience of emotion in human decisions and stimuli to effective decision.

To think systematically is to think about complexity, instability and intersubjectivity. A professional who lives - sees the world and acts in it - the implications of having assumed the aforementioned assumptions, can be considered a systemic 
professional. It must have the gaze of the observer - the Observer as part of the system (VASCONCELOS, 2009).

With the theme outlined, it is proposed to demonstrate the reflections of the adoption of systemic thinking and the influences that this posture can generate in people's lives, answering the following question: it will be possible to achieve efficiency with the adoption of systemic thinking by Public manager?

To achieve the proposed objective, the descriptive method will be used through bibliographic research.

For Fonseca (2002), the bibliographic research is made from the survey of theoretical references already analyzed, and published by written and electronic means, such as books, scientific articles and Web sites pages.

In the next chapter will be presented the concept of public management and, in specific item, the manager. The principle of efficiency will then be addressed in a perfunctory manner. And finally, we will present the systemic thinking and reflections on this look in the construction of a new paradigm of public management.

\section{PUBLIC MANAGEMENT}

In the last 30 years the term "public management" has been used in substitution to public administration and, for this reason, has been considered a polysemic term, since part of the doctrine understands that the two terms are mistaken. Others argue that there was a disruption of the traditional concept, because it encompasses management tools of the business world and, therefore, a broader concept.

Henri Fayol (1950), already in the decade of 50, defined management as administrative functions of predicting, organizing, commanding, coordinating and controlling. 
Since the decade of 80 , the governments of several countries have undertaken efforts to modernize public administration in order to reduce the government's reach and make it work better in the pursuit of agility. The evaluation of the public administration itself changes, and is then balized by criteria close to those used by the private administration.

As a result of this posture arises the New Public Manegement (NPM), associated with the context of a specific reform of the State, whose model is opposed to the conventional public administration, based on the weberianeinjured bureaucracy model consists of conferring a Managerial approach, inspired by the methods of private business management, to the public administration (HOOD, 1995; HERNES, 2005), in order to ensure greater responsiveness and better performance in the provision of public services to the population (MANNING et al., 2009).

Perry and Kraemer (1983) Consider that public management is a merger of the normative orientation of the traditional public administration and the instrumental guidance of management, in a generic sense. In other words, in the first aspect, public management incorporates themes such as democracy and accountability, and values such as equity, equality and probity. And in the second, an instrumental orientation, with the idea that the public sector shares with the private the need to achieve its goals in a more economical and efficient way.

For Druker (1993) management does not refer to the organizational hierarchy of a classical administration, but the ability to promote systematic innovation of knowledge and to take from it the maximum yield in its application to production.

Unlike private management, public management must be guided by social values. It is assumed here, the conception that management is a complex act that brings us closer to the world of politics (BRUGUÉ; SUBIRATS, 1996).

Thinking about the historical evolution of public management, prospectively, refers to a reflection on the true role of the state nowadays. Managing what is public is a complex and challenging act because the scenario is highly competitive. The personal

Disponível em: https://www.nucleodoconhecimento.com.br/business-administration/thoughtsystemic 
vanity and the culture of immediacy prevail in this midst. Each legislature the dynamics of the administration is altered. There is no continuity of actions due to the personality in decision-making, in view of the political influence that ravels the country.

People are terrified by the news of barbaric crimes that are conveed in the media. However, they do not realize that an overpriced or unfinished work, due to mismanagement, may have contributed to the chaos in the education and health of a particular region.

Cardoso Jr (2001) argues that the state's responsibility is not only to do things better and more efficiently. More than this, it is the task of inducing, fostering or even producing the conditions for transforming the economic and social structures of the country. The process involves the redesign of the structure, procedures and practices of the public sector, incorporating changes of great magnitude in the institutional dimension, which include issues related to the principles and values that inform the relationship of such organizations With society and the market (FERLIE et al., 1999; ORMOND LOFFLER, 1999; HERNES, 2005).

In this sense, public management lacks systemic innovation to meet social needs and achieve efficiency. The adoption of systemic thinking by the manager may contribute to new emerging visions becoming shared and collaborative visions. The vision of the whole is fundamental for decision-making.

For Abrúcio (2007), public management has a number of peculiarities that relate to the need to have managerial and democratic instruments to combat the problems that the state faces in the contemporary world. In this context, formalism and bureaucratic rigidity should be attacked as evils, and meritocracy can promote modernization.

Shared vision is the first step in getting people who don't trust each other to start working together. Creates a common identity. (SENGE,2009). Through a culture of feedback, the relationship of trust in the team and the recognition of the effort contribute to the efficiency of public management, as it achieves the aspect related to motivation. 
The manager can transform the concepts (pre) established throughout history. In spite of being tied to the principle of legality, you can make a difference. For this, it must assume a new posture, the systemic look in the pursuit of efficiency, whose concepts and aspects will be discussed below.

\subsection{PUBLIC MANAGER}

According to the classic concept developed by Henri Fayol (1950), the manager is defined by his functions in the organization. It is the person who is responsible for interpreting the objectives proposed by the institution and acts through planning in order to achieve the goals and objectives.

It can then be said that the manager is someone who develops the strategic and operational plan, judges the effective means, conceives the structures and establishes the most appropriate policy rules and procedures and ultimately implements and coordinates the implementation of projects by The middle of a particular type of command (or leadership).

For Chiavenato (2004) to be a manager or leader is to have a global vision, a relationship between man and his work environment. Moreover, it is learning to teach and learn, being the latter of vital importance. Starting for a more subjective premise, Peter Drucker (1993) states that it is through the character that is exercised the leadership. In the same line of thought, Havard (2011) defines that virtue, in addition to being an intrinsic value of the human being, is a dynamic force that increases the capacity for action, a characteristic that is so necessary to the leader. Virtue creates trust, and without trust it becomes impossible to lead.

Being a public manager is a challenge, because managing something that is public is a complex act because of the highly competitive political landscape. In view of the frequent headlines conveed in the media of corruption, deviations from public funds, a paradigm has been established that public services do not serve society efficiently. 
At each parliamentary term, the dynamics of administration is altered, with radical changes occurring. This process is saluting, because otherwise there would be dictatorship or monarchy. However, a continuity of actions and projects is required. It is very important that the manager has science and the notion of how important it is to change posture in the execution of daily tasks and how this attitude can transform people's lives. A wise decision can mean education for needy children in a particular region. More than ever, society cries out for different results. It is necessary to review the traditional process of thinking the public service and implementing new attitudes.

The public manager in the same way as in private initiative needs the characteristics and qualities that enable him to promote the changes that are proposed. As the leaders in the public sector, managers need to be endowed with knowledge, skills and attitudes, as well as a strong vocation to deal with the various forms and sources of power that permeate the public sector (MORGAN, 1996).

The adoption of systemic thinking is intimately linked to the development of the ethical virtues of the manager and/or leader. We can relate some characteristics with the systemic aspects, namely: leadership focused on cooperation and influation, communicability with emphasis on relationships, humanitarianism with emphasis on the process, network thinking, flexibility, Wide vision with totality and dynamism (ANDRADE, 2016).

The action of administering is linked to the practice of systemic thinking and strategic leverage. The characteristics of leadership, in the context of human interaction that favors the processes of optimization of learning, are geared towards the exercise of participation at all levels and for the construction of teams (ZANELLI,2008).

The idea of the ineffectiveness of public services should be abandoned and the political influence reduced. It is necessary to understand that if attention is focused on an isolated part aimed at restricted interests, it will not be possible to perceive the whole system, being fundamental to think about the whole and not in the phases, if you want 
to correct directions and achieve efficiency, whose thematic will be displayed in the following topic.

\section{PRINCIPLE OF EFFICIENCY}

Initially, it is necessary to establish that the administrative principles are basic guidelines that substantiate and support the way of operating public agents, when the attributions linked to public administration are effective.

The principle of efficiency, provided for in art. 37 of the CF of 1988, had its origin in private law, being inserted in the public administration, in administrative reform.

Efficiency in the public sector is a requirement of the new global trend to meet collective interests quickly and with effective results. It seeks a state that plans, develops and performs its functions effectively, making use of new techniques and habits that aim satisfactory results.

The principle of efficiency can be understood in two biases: first in relation to the mode of action of the public agent, which is expected the best possible performance of its attributions, aiming at the best results and, secondly, in relation to the way of organizing, Structure and discipline the public administration, also with the aim of achieving the best results in the provision of public service (DI PIETRO, 2014).

The administrative activity must be conducted by managers committed and concerned with the effectiveness in the provision of public services. The main feature of the manager should be systemic thinking, as a way of visualizing the entire process. Efficient management has the social development as its strand. Therefore, the main objective of the manager should be related to the use of the best means of achieving the satisfaction of collective needs.

The change of posture is linked to the new vision of managers and citizens in relation to the administration of the public thing. It is necessary to detach from the outdated view that the interest of the State overlaps with the private interest. 
Modern constitutionalism not only positioned man at the epicenter of the legal order, guaranteeing differentiated protection of individual fundamental rights, but also tutored interests of a collective nature, which surpass the individual sphere, in The purpose of enabling the enjoyment of rights by all members of the political community (BINENBOJM,2010).

The term public interest should be interpreted as the maximum realization of all interests, individual and collective, legally protected. In the current democratic state of law, the fundamental rights of society overlap and their satisfaction must be pursued by the state above that any other interest.

The lack of control of society over the state, still dominated by particular interests, is indicated as a negative factor in public management. For the Son (2005), the preservation of the private sphere of the individual in conjunction with the promotion of the desires of the political community represents the real public interest to be pursued by the administration.

For efficiency to improve significantly, not only is the democratization of the political system necessary, but the inclusion of internal democratic mechanisms to public administration, which are related to the formation of public policies and the Power sharing in decision-making.

Public managers, citizens and other actors are part of a dynamic, open and interactive system of governance, where the authority of the state is used in different ways to achieve various public outcomes.

In this context, the participation of society has an immeasurable value, as it encourages active citizenship. The empowerment of communities and the civic spirit can make a difference in public management and, consequently, in the results of public services delivered by the state.

On the other hand, the public manager should reflect his actions, under the aegis of systemic thought, whose theme will be discussed below. 


\section{SYSTEMIC THINKING}

Through the act of thinking, human beings model the world, interacting according to their desires, plans and goals. The concepts and processes of cognition, sentience, Consciousness and Imagination (ANDRADE, 2016) can be associated with thinking. With a focus on the evolution of science, we can cite the predominant Cartesian, complex and systemic thoughts.

The systemic thought arose in the TWENTIETH century, opposed to the reductionistmechanistic thought of Descartes and Newton, which is based on the traditional science paradigm referred to by Vasconcellos (2009), whose basic assumptions are summarized in Simplicity, stability and objectivity.

The assumption of simplicity is based on the belief that it is necessary to separate the parties to understand the whole. In this Look, Cunha (2006) interprets that the reduction is another operation in search of simplicity, which unifies what is diverse. By finding a complex phenomenon, the scientist seeks its reduction to another simpler and already well understood phenomenon.

The assumption of stability lies in the belief that there is stability in the world and there are repetitions regularly. Under the assumption of objectivity, it constitutes the belief that it is possible to know the world as it is composed in reality, considering the essential criterion of scientific thought (CUNHA, 2006).

The paradigm of traditional science, through linear-cartesian thinking, developed and established itself in the physical and exact sciences, becoming a model of scientificity. The physicists acted based on the assumptions of simplicity, stability and objectivity, and succeeded, explaining the physical world and developing sophisticated technologies that increasingly modified the relationships of Man with nature (VASCONCELLOS, 2009).

With the convictions that there is a difference between human beings and nature, and that human phenomena are of a subjective nature, the rupture between nature

Disponível em: https://www.nucleodoconhecimento.com.br/business-administration/thoughtsystemic 
Sciences (objective) and human sciences has been established. According to Vasconcellos (2009), the physical sciences easily adopted the three epistemological assumptions. The biological sciences adopted the assumption of objectivity, and had problems with those of simplicity and stability, while the humanities had difficulties in relation to the three assumptions, in particular, that of objectivity.

The systemic thinking proposes, in contrast, the paradigms of complexity, instability and intersubjectivity, which integrate incredibly with the analytical psychology of Carl Gustav Jung (VASCONCELLOS, 2009).

A professional who lives, sees the world and acts in it the implications of having assumed for himself the assumptions of complexity, instability and intersubjectivity can be considered a systemic professional (VASCONCELLOS, 2009).

The systemic paradigm, which considers the assumptions of complexity, subjectivity, instability, has as principles the flexibility and plasticity that are manifested in the systems through Auto-organizativas characteristics that, from the chaos, Assumes aspects of self-renewal and auto-transcedence. Thus, open systems far from equilibrium can preserve, reproduce, renew, adapt and evolve. Thus, the processes of adaptation on one side and the other are evident, those of learning, development and Evolution (COSTA, 2007).

Cunha (2006) expresses the notion that systemic thinking means thinking in terms of connections, relationships, context, interactions of the elements of a whole; To see things in terms of networks, webs and communities.

Systemic thinking does not deny scientific rationality, but believes that it does not provide sufficient parameters for human development and for the description of the material universe. For this reason, it seeks to look in the opposite direction of reductionism, giving greater emphasis to the whole than apart.

It presupposes a methodology of thinking processes, which configure the existence of the whole. That is, it is necessary to study the systems globally, in order to involve all 
their interdependencies, because each of the elements, when assembled to constitute a larger functional unit, develop qualities that are not in their components Isolates (BERTALANFFY, 2009).

Capra (1996) argues that fragmented thinking is not capable of addressing the interconnectedness of global problems, both at the higher levels of society and at the individual level. In this sense, the essence of systemic thinking is in the change of mentality, which means seeing interrelationships instead of cause-effect linear chains and seeing processes of change rather than snapshots (Senge, 2009). In this gathering, changes should not be thought of as isolated actions, but as a set of interdependent measures that are part of the planning of improvements of the organization.

It is a way of analyzing and thinking the knowledge about the world, through systems. A systemic view or "systemic thinking" means to keep in mind what one wants to solve, choosing the right or the most appropriate way. It can be said that this is a skill that an individual acquires to analyze the events and their possible consequences, with the aim of creating a unique solution that contemplates the expectations of all the parties involved.

In both private and public management, there is no uniformity in the adoption of systemic thinking by managers. Most public agents don't even know the concept. It can be reaffirmed the importance of systemic thinking in management through Zanelli's words:

The action of administering is linked to the practice of systemic thinking and strategic leverage. The characteristics of leadership, in the context of human interaction that privileges the processes of optimization of learning, are geared towards the exercise of participation at all levels and for the construction of teams (ZANELLI,2008, p. 13).

In 2008, the National Quality Foundation (FNQ), present in the most prestigious world models of excellence, conducted a virtual survey with 196 Brazilian executives. The 
results revealed that the majority of respondents knew only partially the concept of systemic thinking.

The great concern of systemic scientists is the recognition that the need for a profound change of perception and thought, to ensure survival, has not yet reached the majority of managers, nor the administrators and teachers of Our major universities (CAPRA, 1996).

When people perceive the world differently, new beliefs and assumptions emerge, which enables the development of new skills and capacities, forming a continuous cycle of organizational learning.

Peter Senge (2009) Places that systemic thinking can be presented as a discipline, a study with theory and practice, which allows to develop the vision of assembly, a structure to see the interrelationships in place of things, to see patterns of change In place of static ' snapshots '. The manager, as he adopts systemic thinking, can make a difference in public management and change the reality of the country. With this new look, you can conduct the actions of the institution, interpreting policies and procedures and adapting the processes and internal practices to the requirements defined by law.

It takes innovation in public management. The manager has to take the role and stops acting as mere supporting, performing the tasks with courage. To think systematically for the sake of social welfare.

It is a complex theme, because the change of posture of the manager, in adopting systemic thinking in the exercise of management, is related to subjective criteria, such as character, whose virtue is not measured or assessed when the entry of this Professional in public activity, irrespective of whether it was by public tender or nomination by nomination.

However, as presented in the research, public management is in increasing progress, expanding the political capacity of the state to "do well the policy" to better serve the society and therefore achieve efficiency. More and more authors advocate the 
theoretical abandonment of the principle of supremacy. Public interests and private interests are clearly not antagonistic, but rather complementary (JUSTEN FILHO, 2005) categories.

The research allowed us to infer that the application of the concepts of systemic thinking can add significant value to several areas of research and in sectors in organizations. In this sense, the use of the systemic approach in other areas can be revealed as a relevant academic contribution.

Thus, it is valid to affirm that the objective of this study was achieved, and it is possible to affirm that the adoption of systemic thinking by the manager is directly related to the principle of efficiency.

For future studies, it is proposed to conduct researches in public administration organs, with the objective of verifying the systemic behavioral characteristics of managers, suggesting practices to systemic management with a focus on people's behavior .

\section{FINAL CONSIDERATIONS}

After analyzing the documents found in the literature, it was possible to identify that the adoption of systemic thinking by the manager can influence the direction of public management of the country. This is a skill that an individual acquires to analyze the events and their possible consequences, with the aim of creating a unique solution that contemplates the expectations of all the parties involved. The benefits of this new vision/posture may be visible in the services rendered to society and internal actions of the institution, because it is directly related to decision-making.

To this end, the public manager, in the same way as in private initiative, needs the characteristics and qualities that enable him to promote the changes that are proposed. As the leaders of the public sector, managers need to be endowed with knowledge, skills and attitudes, as well as a strong vocation to deal with the various forms and sources of power that permeate the public sector (MORGAN, 1996). 
The adoption of systemic thinking is intimately linked to the development of the ethical virtues of the manager. The worldview is individual. Soon, there is no way to have a unit or control in the manner of thinking and acting. In this conjuncture, it should not be thought of changes as isolated actions, but as a set of independent measures that are part of the planning of improvements of the organization.

Systemic thinking "helps to understand how to change systems more effectively and how to act in better harmony with the processes of the natural and Social world" (VALENÇA, 2011).

The organizations that will truly succeed in the future will be those who discover how to cultivate in people the commitment and ability to learn at all levels of the Organization (SENGE,2009).

Therefore, it should be considered that the present study intends to discuss a still incipient perspective on a strategic theme for public agencies in terms of management, with no intention of exhausting the subject.

\section{REFERENCES}

ABRUCIO, Fernando Luiz. Trajetória recente da gestão pública brasileira: um balanço crítico e a renovação da agenda de reformas. Edição Especial Comemorativa. Rio de Janeiro: Revista de Administração Pública (RAP), 2007.

ALVAREZ, Maria Esmeralda Ballestero. Organização, sistemas e métodos. São Paulo: McGraw-Hill, 1990.

ALVES, João Bosco da Mota. Teoria Geral de Sistemas - Em busca da interdisciplinaridade. Florianópolis. Instituto Stela, 2012.

AMARAL, Antônio Carlos Cintra do. O princípio da eficiência no direito administrativo. Revista Diálogo Jurídico, Salvador, CAJ - Centro de Atualização Jurídica, n.14, jun./ago. 2002. 
ANDRADE, A; Rodrigues, L; Seleme A; Souto, R; Pensamento sistêmico: Caderno de campo. $O$ desafio da mudança sustentada nas organizações e na sociedade. Porto Alegre: Bookman, 2006.

BINENBOJM, Gustavo. Da Supremacia do Interesse Público ao Dever de Proporcionalidade: Um novo paradigma para o Direito Administrativo. In: SARMENTO, Daniel (org.). Interesses públicos versus Interesses privados: desconstruindo o princípio da supremacia do interesse público. Rio de Janeiro: Lumen Juris, 2010.

BERTALANFFY, L. von. Teoria Geral dos Sistemas: Fundamentos, desenvolvimento e aplicações. São Paulo: Editora Fundação Perseu Abramo, 2006.

BRASIL. Constituição da republica Federativa do Brasil: 1988. 25. Ed. Brasília: Câmara dos Deputados, Coordenação de Publicações, 2012.

CÂMARA, Leonor Moreira. Fatores do Pensamento Sistêmico como Potencializadores de Sucesso de Projetos de Software no Setor Público.organização da administração pública Federal Brasileira: uma introdução ao estudo da organização da direção pública na perspectiva de estudos organizacionais. Rio de Janeiro: Revista de Administração Pública (RAP), 43(3), maio/junho 2009.

CAPRA, F. O Ponto de Mutação. A ciência, a sociedade e a cultura emergente. Trad. Álvaro Cabral, São Paulo: Cultrix, 2006.

CAPRA, Fritjof. A Teia da Vida. Uma Compreensão Cientifica dos Sistemas Vivos. São Paulo (SP). Editora Cultrix. 1997.

CARNEIRO, R., MENICUCCI, TMG. Gestão pública no século XXI: as reformas pendentes. In Fundação Oswaldo Cruz. A saúde no Brasil em 2030 - prospecção estratégica do sistema de saúde brasileiro: desenvolvimento, Estado e políticas de saúde [online]. Rio de Janeiro: Fiocruz//pea/Ministério da Saúde/Secretaria de 
Assuntos Estratégicos da Presidência da República, 2013. Vol. 1. pp. 135-194. ISBN 978-85-8110-015-9. AvailablefromSciELO Books.

CHIAVENATO, Idalberto. Recursos Humanos. O Capital Humano das Oganizações. SãoPaulo:Atlas, 2004.

CHIAVENATO, Idalberto. Iniciação à Organizações e Controle.São Paulo: McGrawHill, 1989.

COSTA, WedjaJosefa Granja. Socionomia de base sistêmica: Método de apoio à gestão de grupos na organização. Dissertação de Mestrado. Fortaleza: Universidade Federal do Ceará, 2007.

CUNHA, Aura Celeste Santana. Pensamento Sistêmico e tecnologia educacional: a metodologia WEBQUEST. Dissertação de Mestrado Profissional em Computação. Fortaleza: Universidade Estadual do Ceará, 2006.

DRUCKER, Peter. The effective executive. Harper Collins Publishers, 1993.

DRUCKER, Peter F. Administrando para o Futuro: os anos 90 e a virada do século. Tradução de Nivaldo Montigelli Jr. São Paulo: Pioneira Thomson Learning, 2002.

FALCONI, Vicente. O verdadeiro Poder.Nova Lima: INDG Tecnologia e Serviços Ltda. 2009.

FAYOL, Henri. Administração Industrial e Geral.São Paulo. Atlas, 1990.

FLEURY, S. J. F. Redes de proteção: incentivos, escolhas e comportamentos na política brasileira. 2009. Tese (Doutorado) - Faculdade de Filosofia e Ciências Humanas da Universidade Federal de Minas Gerais, Belo Horizonte, 2009. 
HERNES, T. Four ideal-types organizational responses to the new public management reforms and some consequences. International Review of Administrative Sciences, v. 71, n. 1, p. 5-17, 2005.

HOOD, C. A public management for all seasons? Public Administration, . 69, $\mathrm{n}$. $1,1991$.

JUSTEN FILHO, Marçal. Curso de Direito Administrativo. São Paulo: Saraiva, 2005.

GOMES, Lauren Beltrão et al . As origens do pensamento sistêmico: das partes para o todo. Pensando familiar, Porto Alegre, 2014.

KOLTER, John P. Liderando Mudanças. Rio de Janeiro: Elsevier, 2013.

LAKATOS, Eva Maria; MARCONI, Mariana de Andrade. Fundamentos de Metodologia Científica. 4 ed. São Paulo: Atlas, 2001.

LIMA, Joilson Souza de. O Planejamento Estratégico como Ferramenta de Gestão. Revista Científica Multidisciplinar Núcleo do Conhecimento. Ano 03, Ed. 03, Vol. 03, pp. 58-69, Março de 2018. ISSN:2448-0959.

MEIRELLES, Hely Lopes. Direito Administrativo Brasileiro. São Paulo: Malheiros, 2002.

MANNING, N. et al. Reformas de gestão pública: o que a América Latina tem a aprender com a OCDE.In: MEDEIROS, P. C.; LEVY, E. (Orgs.). Novos caminhos da gestão pública: olhares e dilemas. Rio de Janeiro: Qualitymark; Brasília: CONSAD, 2009. p. 97-148.

MORAES, Germana de Oliveira. Controle Jurisdicional da Administração Pública. São Paulo: Dialética, 1999, p. 127.

MORGAN, Goreth. Imagens da Organização. São Paulo: Atlas, 1996. 
PIETRO, Maria Sylvia Zanella Di. Direito Administrativo. São Paulo: Atlas, 2002.

SENGE, Peter M. A quinta disciplina: arte e prática da organização que aprende. $25^{\mathrm{a}}$ ed. Rio de Janeiro: BestSeller, 2009.

SEMLER, Ricardo. Virando a própria Mesa: Uma história de Sucesso Empresarial. Rio de Janeiro, 2002.

VALENÇA, Antônio Carlos. Aprendizagem Organizacional: 123 aplicações práticas de arqueótipos sistêmicos. São Paulo:SENAC, 2011.

VASCONCELLOS, Maria José Esteves. Pensamento Sistêmico: O novo paradigma da ciência. 9aㅗ ed. Campinas-SP: Papirus,2010.

ZANELLI, José Carlos. Interação Humana e Gestão: a construção psicossocial das organizações de trabalho. São Paulo: Casa do Psicólogo, 2008.

Submitted: October, 2019.

Approved: October, 2019. 